\title{
Public Intellectuals, Information Politics and the Manichean Moment
}

\author{
Dion Dennis
}

This essay is less about an abstract set of practices and more about examining the actual, probable, and possible roles (or nonroles) of intellectuals (and those who would claim such roles) in the early-twenty-first century. To do so, we must take note of some constitutive features of contemporary life, as they relate to those who would speak as American intellectuals.

First, we think, speak, and act in a post- $9 / 11$ social and political environment. The events of $9 / 11$ reconstituted the United States, in the post-Cold War world, as a fundamentally insecure society, a society increasingly obsessed with its own physical security, fretful about its economic future, and the escalating costs of maintaining an aging generation of baby boomers. When combined with the reframing of post-secondary education as a private, rather than a public good (which has simultaneously facilitated state disinvestment of higher education while jumpstarting serial double-digit increases in post-secondary tuition and fees), the evangelists of the market face escalating doubts and anxieties among the members of their diverse congregation. We think, write, speak, and act in a social environment constituted by these durable structural tensions.

Secondly, a key assumption (of this essay) is that institutions of knowledge production and reproduction matter in American life. For whom they matter, how they matter, and why they matter reveal widely divergent agendas and world views (emphasizing everything from critical engagement with new forms of communication to the econometric goal of producing obedient, efficient, and depoliticized technocrats for social control).

Thirdly, intellectuals (like politicians, artists, ersatz entertainers, propagandists, televangelists, commodity marketers, PR agencies, and con men) primarily communicate to larger publics via evolving audio, televisual, and webaccessible textual and multi-media forms. Today's words, images and deeds will remain visible, audible, and retrievable, months, years, and decades later. Utterances initially addressed to specific audiences may be reframed, at any point in time, seamlessly inserted into alternative narratives, and recirculated in new contexts. The key factor enabling such rapid and prolific recontextualization is the intensification of routine information collection, storage, and the equally intensive, speedy distribution of these images, sounds, data, and signifiers, across the planet. Collectively, such technological ensembles can be collectively understood as "surveillant assemblages." As Haggerty and Ericson (2000) put it, surveillant assemblages facilitate the end of anonymity, or "the disappearance of disappearance" (pp. 605-622). As the myriad devices that compromise the hardware of such surveillant assemblages become cheap, ubiquitous and multifunctional, their integration into the routines of everyday life reconfigures everyday life. The result of such integration often renders the traditional dramaturgical distinctions of front-stage, back-stage and offstage behaviors moot. Collectively, these behaviors are increasingly blended into variants of restylized front-stage presentations, inserted into multi-media formats, and circulated via high-speed networks.

What follows below is an embedded examination of the intellectual as a contested and active agents and icon, represented and representing, in media formats and worlds. What happens when, in one prominent and current case, prominent figures on the left and right rigidly cleave to preset ideological commitments, in the midst of controversy and scandal? Such a pattern of unreflexive and polarized reactions prompts us to ask: What does it mean to be a responsible and responsive intellectual, in the current environment? How does one practice responsible dissent and critique, at this point in our social and political history? What does it mean to "tell the truth," in these times? Perhaps 
we have something to learn by analyzing a still unfolding case.

\section{The Manichean Present: Iteration One}

On the evening of September 11, 2001 at least two academics were at their computers, trying to make some broader sense of the World Trade Center attacks. After rapid editorial reviews, my "The World Trade Center and the Rise of the Security State" was published in CTHEORY on September 18, 2001. Assessing six decades of U.S. ideology and practice, the article predicted that the WTC attack marked a transition to a third period in post-WW II U.S. society, a period that I characterized as "a society of security."

It's now clear that we simultaneously entered an extended phase of political and moral rhetoric characterized by vivid and tightly held Manichean constructions of self and the world (Boyte 2002)[1]. For example, in my "Priming the Pump of War" (2002; 2004:117-125), I explored how the politicized Christian billionaire, Philip Anschutz, bankrolled an aggressive, extensive and sophisticated public relations campaign, in the pre-Iraqi War period, through his "Foundation for a Better Life" (FBL). The America constituted on the web pages of the Foundation's site (and in the public service announcements still playing on the 6000 movie screens that Anschutz controls as well as in cable television feeds) is concurrently evoked in the moralistic propaganda posted on thousands of billboards lining the interstate highways and bus stops in predominately "red" states. Part Norman Rockwell, part Norman Vincent Peale, the FBL campaign evokes an imagined past that never was, as the oddly conflated images and accompanying narratives of "simple virtues" facilitate a nostalgic hypernationalism, and a fantasy of simple unity in pursuit of a common destiny. As a form of "soft propaganda," the images and scripts of the FBL resonate with Goebbels' valorization of the simple and true virtues of "Der Volk," across the Third Reich, in the late 1930s. Like these Goebbelian images, Anschutz's FBL imagery remains a potential precursor for future violence.

In Boulder, we encounter the second academic: Just as Elijah Muhammad inverted Manichean racial representations without changing the fundamental binary modus operandi of the machinery, so, on the night of September 11, 2001, Ward Churchill (2001) enthusiastically and self-righteously keyboarded an article, "Some People Push Back: On the Justice of Roosting Chickens." Astounding in the sheer number of inaccuracies and gross simplifications of geopolitical reality, Churchill casts Al Qaeda as if they were a bank of Jedi Knights, implicitly assigning to Osama bin Laden the role of Luke Skywalker, nobly striking back at the Empire and its functionaries (such as Madeleine Albright, who Churchill compares to "Jaba the Hutt" [sic]). For Churchill (2001), the attacks represented

a certain optimism [and] humanitarianism ... a medicinal aspect ... a tonic ... [the perpetrators] manifested the courage of their convictions... [administered] reality therapy ... [are not] unreasonable or vindictive ... [these acts represent] gallant sacrifices... [but] the dosage of medicine administered [through the attacks] was entirely insufficient to accomplish its purpose.

These are all unqualified kudos typical of a Manichean discourse. For Churchill to sustain it, a very selective ahistorical memory and narrative is required. For example, when Churchill proclaims that "Middle Easterners, unlike Americans, have no history of exterminating others ...," he omits significant regional events, such as, the Ottoman genocide of Armenians, the more recent Iraqi and Turkish campaigns against Kurds, complexities around the Lebanese Civil War, the repressive and gendered governance of Afghanistan by the Taliban, the historical persecution of Sufis and Bahais, or the latter twentieth century violence in several states of the Caucasus.

Like other, more accomplished propagandists, Churchill rhetorically devalues his target. Answering his own [implicit rhetorical] question, "Who are Americans?", Churchill casually tosses off a global generalization. Of course, Americans are a homogeneous and trivial people who uniformly

[Obsess about] getting "Jeremy" and "Ellington" to their weekly soccer game, or [ensuring] little "Tiffany" and "Ashley" have just the right roll-neck sweaters ... American adults [are] much closer to [embodying] Pavlovian stimulus-response patterns than ... higher logic...

In Churchill's ür-narrative, all people of color are inherently virtuous, and whites, by virtue of their subject position and pigmentation, are of a lower moral order. Such broad, essentialist caricatures typify identity politics at its worst. Apart from essentialist problematic, questions have been raised about the academic quality of Churchill's 
work, and multiple (and contested) charges of plagiarism. The responses of some prominent left-intellectuals, to Churchill's work and situation, have been simultaneously revealing and disappointing. As University of Colorado law professor Paul Campos (2005) pungently observed, preset and rigid ideological commitments may cause both a profound political ineptness as well as permanent blindness.

\section{The Immediate Lesson}

First, far from being either insightful or truly critical/radical, Churchill's discourse strengthens one pole of the current idée fixe, the present Manichean political and cultural frame. Right-wing purveyors of the current Manichean militarism recognize (and perhaps secretly celebrate, for tactical reasons) Churchill as the new Whittaker Chambers. He becomes the necessary example of the enemy within, of the intolerant poisoning the minds of a generation. For them, Churchill signifies a deeply embedded cancer in the body of the academe that must be aggressively countered with an immediate antidote. For Manicheans on the far right, this man is a gift: Irrational in his exuberance for retributional attacks, and arguably under-credentialed for his position, Churchill is sold to the body politic, by corporate news media and right-wing tacticians, as representative of all contemporary secular academics (Churchill signifies all that is wrong with those secular, flag-hating post-secondary institutions that the children of the disappearing traditional working class now must pass through, to compete in global labor markets.). In a society of everyday fear, it's fair to paraphrase Voltaire, in imagining the ideological usefulness of this academic for the right: "If Churchill didn't exist, we would have to invent him."

But there is no need to invent Churchill. Instead, he is placed in a peculiar satantheon. Accompanied by an "enemy of the people" inflected dossier served up in the format of a quasi-baseball trading card, Churchill's visage is added to the Manichaeistic "Campus Support of Terrorism" sub page on David Horowitz's detailed website, "DiscovertheNetwork.org: A Guide to the Political Left". Furthermore, it is to Horowitz, his staff, and his alternative form of Manichaeism that we now turn.

\section{The Manichean Present, Iteration Two: A Horowitz of Horrors}

According to its Geist, David Horowitz, Discoverthenetwork.org (launched on February 14, 2005) is a "Guide to the Political Left:"

It identifies the individuals and organizations that make up the left and also the institutions that fund and sustain it; it maps the paths through which the left exerts its influence [and promotes hidden] programmatic agendas...

The site is made up of two elements along with a powerful search engine ... The first of these elements is a database of PROFILES of [1500] individuals, groups and institutions [in the form of] thumbnail sketches of histories, agendas and funding sources...

The second data element of this site consists of a library of articles, which analyze the relationships disclosed in the database and the issues they raise. These analyses are drawn from thousands of articles, both scholarly and journalistic, that have been entered into the base and linked in the TEXT columns that appear on the PROFILE pages.

All of this is in service of tracing the paths by which these radicals were able to influence institutions like the Democratic Party... One can thus trace the progress of a radical [leftwing] menu ... into the heart of the American political mainstream.

DiscovertheNetwork.org is organized into many (and still developing) sub pages such as "left-wing millionaires club," "left-wing prizes," "funders," "academia," and "individuals." The "individuals" page is a prototypical example. On that page, each photo, in an overall array, is hyperlinked to dossiers on separate pages. The catalog's opening page features such diverse figures, arranged in a series of thumbnail photos, from right to left, in a presumed taxonomy of subversion, from George Clooney and Garrison Keillor ("affective leftists"), to Roger Ebert ("moderate leftists"), and Supreme Court Justice Ruth Ginsburg ("leftists"), to Michael Moore and Tom Hayden ("anti-American radicals") and finally, to Mohammad Atta and the abovementioned Ward Churchill ("totalitarian radicals"). The array functions as a gradated taxonomy of presumably corrosive influences. For Horowitz and his allies, all of these insidious "types" are inadvertently or advertently degrading the security of the American Republic. See the screen snapshot below: 


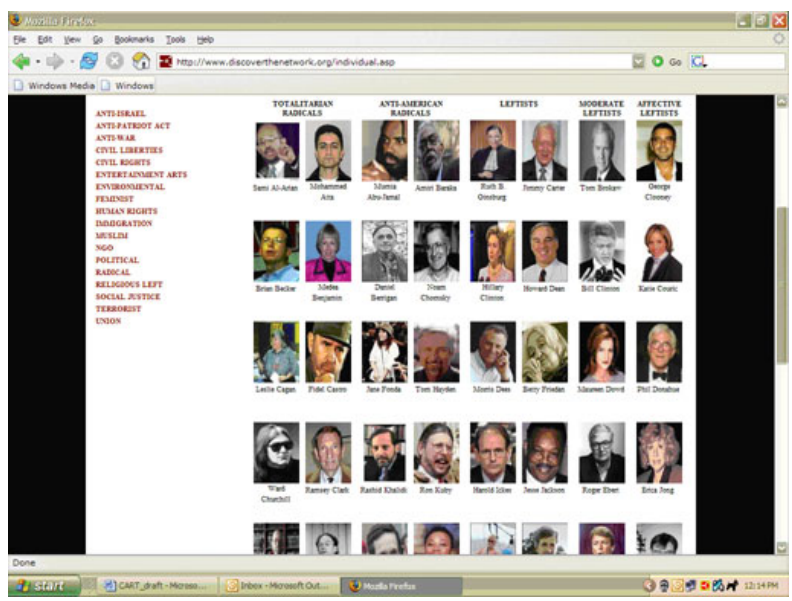

Figure 1. A Web Page Snapshot of Horowitz's Inaugural Taxonomy: A Cohort of Agents Presumed to be Differentially Dangerous to the American Republic.

At the top of this web page, Horowitz (2005) explains the organizing logic behind a taxonomy that constructs these stigmatizing associative connotations:

[The taxonomy's] organizing basis is [formed by] a commitment to egalitarian goals and social constructionist assumptions ... and-in its radical wing - a nihilistic opposition to global capitalism, now referred to as "globalization." These radicals reject the ... alleged "hierarchies" of western democratic capitalism, and regard America as the arch imperialist power and guarantor of private property globally. That is the reason for the inclusion of Islamic radicals alongside American[s] ...

As a form of information politics on the web, Discoverthenetwork.org inverts Richard Rogers' (2004) naïvely propagated utopian notion of a Western European information and activist Internet as the sole property of "progressives" for eliding corporatist news media. Instead, Horowitz demonstrates a different use for web-based information politics: Horowitz catalogs the networks that fund "so-called" dissenters. Detailed "think maps" show how such presumably "insidious" networks are allegedly (if indirectly) connected to my Ph.D. Alma Mater, Arizona State University:

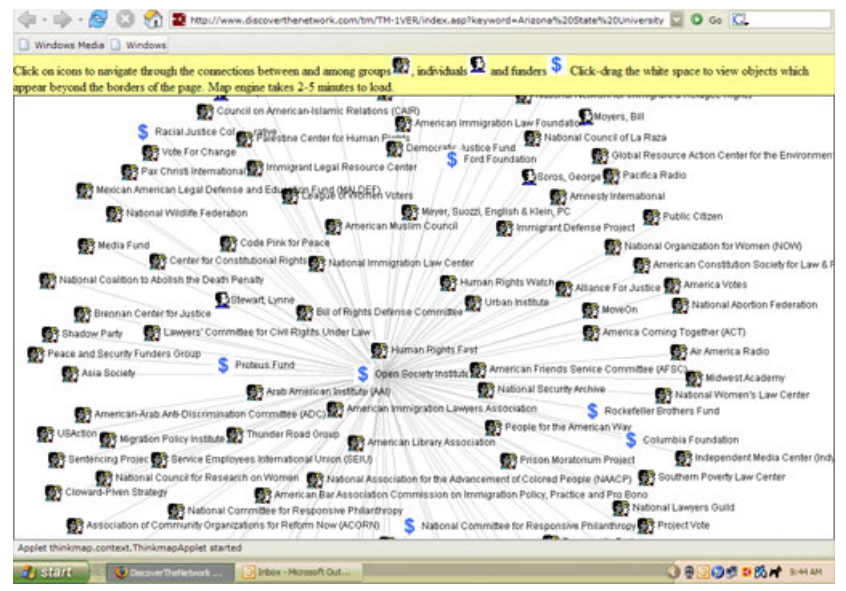

Figure 2. A Snapshot of A "Think Map" that "Reveals" the Presumably Nefarious "Leftist” Network Around Arizona State University 
In Horowitz's Manichean vision, this neo-construction of diverse organizations and agendas are connected to each other through presumably unwholesome funding mechanisms and agencies, such as Soros' Open Society Institute, the Proteus Fund, the Ford Foundation, the National Committee for Responsive Philanthropy, and the Carnegie, Target and Verizon Foundations (among others).

Clearly, if the technology had been available, certainly these kinds of digital network maps would have been first assembled, and then accompanied by lurid and dark narratives, during the HUAC/McCarthy hearings of the 1940s and 1950s. As Scott Sherman (2000) has documented, much of the Horowitz's language reprises the sensibility of "the Red Scare." Fears about an internal army of traitors, known in the mid-twentieth century as "The Fifth Column," are now folded, into yet another science-fiction moniker, "The Shadow Party." (Just as Churchill's plumbs the "Star Wars" proto-narrative, Horowitz plumbs the narrative from the mid-1990s sci-fi series, "Babylon 5"). According to Horowitz (2005a), "The Shadow Party" consists

[of] without exception, [of] groups and individuals [who are] anti-corporatist and socialist (often Marxist-Leninist), rather than pacifists and non-violent or merely liberal, as described in the general media. Their opposition to the war went well beyond the issue of the war itself.

For Horowitz, this "Shadow Party," stealthily promotes agendas that "are rooted in their radical opposition to the American status quo." Other nested pages on Horowitz's site echo the transposition of 1950s Cold War rhetoric in even greater detail. Consider the following example: In describing a linked site devoted to similar tasks, "The Center for the Study of Popular Culture" is depicted as follows:

The Center for the Study of Popular Culture ... is dedicated to defending the cultural foundations of a free society, a task made even more pressing by the attack on America of September 11th, the Iraq conflict and the internal opponents of freedom this attack has revealed. The Center is led by ... David Horowitz ... who has been called "the left's most brilliant and articulate nemesis,... (Horowitz 2005b)

In this formulation, "the internal opponents of freedom that this attack revealed" refers to those who would level any criticism of the Iraq War, or question the curtailment of civil liberties represented by some sections of the Patriot Act. (Presumably, even Peter Drucker would be placed on this list). For Horowitz and his minions, then, domestic dissent to Bush Administration's policies is the functional equivalent to an attack on America. In this formulation, dissent is terrorism. Substitute the word "communism" for "terrorism," and the resonance is easily discernable. Ostensibly, freedom is constituted by the lack of dissent. It is de facto wedded to blind obedience and ideological dogma, in Horowitz's worldview. As an ex-60s radical, Horowitz knows that many forms of political dissent, with differential but sometimes substantial claims of authority, often emerge from college and university campuses.

DiscovertheNetwork.org is a new and still developing site, but it exhibits a number of very familiar, if somewhat cartoonish, propaganda techniques, including unflattering and distorted photographs of ideological "enemies;" reductive and slanted mini-biographies, which are sprinkled with a patina of reasonableness and an ersatz appeal to "objectivity."

\section{The Common Thread}

Taken as the two faces of contemporary Manichaeism, Churchill and Horowitz, and the great majority of their academic and extra-academic allies, embody a recognizable iteration within American politics. Richard Hofstadter (1964) collectively framed such worldviews as epitomizing “'The Paranoid Style in American Politics.” For Hofstadter,

The paranoid spokesman sees the fate of conspiracy in apocalyptic terms-he traffics in the birth and death of whole worlds, whole political orders, whole systems of human values. He is always manning the barricades .... Perceiving the conspiracy before it is fully obvious to an as yet unaroused public, the paranoid is a militant leader [who] does not see social conflict as something to be mediated and compromised ... What is necessary is ... the will to fight to [the] finish. Since the enemy is thought of as being totally evil and totally unappeasable, he must be totally eliminated ... at least from the theatre of operations ... Partial success leaves him with [a] feeling of powerlessness ... The enemy is ... [an] amoral superman-sinister, ubiquitous, powerful, cruel ... He wills ... the mechanism of history ... in an evil way. The paranoid's interpretation of history is distinctly personal: decisive events are ... the consequences of someone's will. Very often the enemy is held to 
possess some especially effective source of power.

From inverted ideological starting points, both Ward Churchill and David Horowitz embody the same Manichean impulse. Injected into campus life, as they are today, each represents a grave danger. For the potential hegemony of any Manichean narrative, whether it comes either from the ideological ground of a Ward Churchill or a David Horowitz, will always be a pedagogical disaster. In their global and paranoid aspects, Manichean narratives are inherently destructive of the process of education. They are monologic. They produce invective, fear, silence, degradation, marginalization, sullen obedience, and alienation. Manichean worldviews, left or right, preclude productive encounters with difference and diversity, and stifle the possibility of taking thought and perception into the unknown. As such, any such Manichaeistic hegemony precludes dialogue. And, after millennia of educational practices, dialogue remains as the beating heart of education. In that sense, the monologic stances of Ward Churchill and David Horowitz constitute competing manifestations of the same impulse. As icons, they stand for entire networks, but as individuals, they are but two of the hydra-heads emanating from the singular Manichean Medusa. But, these two Manichean hydra-heads have very different understandings of mediated communication, and have different resources in tow. And it is to this that we now turn.

\section{Reprising the 1960s via Mediated Information Politics: Impulsivity, Contingency, and Tactics}

On March 18th, the Associated Press featured a series of short quotes from Ward Churchill (2005), presumably from recent interviews, such as the one below:

I don't think anybody expected this. I can't say I . . plan[ned ] it. I'd like to say that's how effective my method is. . . I riveted the entire nation on-what did I rivet the entire nation's attention on? It's just boilerplate now ...

In the midst of a self-described weariness, Churchill preferred the conceit that he produced a meta-pedagogical moment, in the form of a national epiphany. But in the light of reality, he backed off, admitting that "he'd never thought that he'd become the poster boy for academic freedom."

But Churchill is far more than that. He has become a contested media icon, an over-coded ideological signifier, with different resonances for different audiences. His iconic status was a potential wrapped in a contingency, a marginality transported to the center of national political, cultural and academic life. This academic cause cerebra was technologically-driven, via a non-linear iteration of mediated representations, artifacts (such as audio recordings, answering machine messages, copies of allegedly plagiarized art, news footage), events, media tactics and strategies. As of late March 2005 textual and multi-media representations of Churchill are distributed across thousands of web sites, and blogs. Tactically inept in assessing the effect of his utterances in a multi-media information-distribution environment, an angry, self-absorbed, self-righteous, and bizarrely bumbling Churchill has been an easy target. Here's how Horowitz's cybercronies recently assessed Churchill's (and technology's) usefulness for the right, on another Manichaeistic web site, www.frontpagemag.com. The title of the transcript is "Symposium: Can the University Be Fixed?" (Glazov 2005) Next to the title is this rhetorical invitation that is strongly reminiscent of the Cold War. The site editors invite the readers to send this web page to their personal "ebrigade." On these pages, Glazov and Horowitz's fellow travelers / cybercronies articulate tactics and strategies:

David Warren Saxe: Fixing universities? ... How does Ward Churchill fit into this? Administrators ... open[ed] doors for the unqualified ... [It's] ... affirmative action for faculty... Ward Churchill would have never been hired ... unless somebody lowered the standards. How did this "Irish-English" white man get in, he claimed he was an Indian...

Schweikart: In most universities ... the inmates are running the asylum. Every position [that involves] a "women's history" . .. requires ... radical feminists [who] can hire [only] a radical feminist. The same is seen with "ethnic" or "minority" hires ...

Kerney: Step One in reforming colleges and universities: Technology [is] enabling a dramatic power [shift in] information gate-keeping .... The next step ... is to increase broadband ... accelerate ... ubiquitous fast wireless [in] education. When kids come to college with values far removed from that of their professors ....and are equipped with sufficient knowledge to deal with ... professors, then reform will [come]... 
Saxe: Technology [will] undermine ... proselytizing professors ... (Glazov 2005)

The assumptions of techno-determinism (and the unidirectionality of surveillance and representation that frame this monologue of the like-minded) are inherently suspect. (For example, Horowitz, who shares with Churchill the intemperance that comes with Manichaeistic zealotry, has recently been caught, by other advocacy websites, such as Media Matters, seriously misrepresenting student complaints at Foothills College and the University of Northern Colorado). And, given what we know about social change, it's also fair to say that those who smugly advocate a technologically-driven historical determinism will run afoul of the law of unintended consequences. It's equally fair to say that these right-of-center activists have substantial funding, allies across a number of institutions, from academe to corporatist media (such as Murdoch's Fox News) and astute mentors, in think-tanks, public relations and politics. Taken as a whole, it's easy to discern a well-coordinated, and very determined tactical and strategic "game plan," writ large. Much of the overall strategy is enabled by a continuous panspectral collection of data, images, audio, and text, as we witnessed in Churchill's ongoing case. Dataveillance is a task that Horowitz and his cronies are clearly dedicated to. Melded with finely honed skills (deftly practiced by other tacticians, such as Ted Jackson) in political "brand management," and an impressive range of propaganda techniques that would make the late Edward Bernays proud, it's a formidable, but contestable, mix for shaping "the definition of the situation." Given Churchill's profound ineptness and/or ignorance with the contemporary mix of multi-media formats, the array has plowed Churchill and his ideological allies into "a definition of the situation" akin to permanent stigmatization. Misreading the times, misreading opponents, misreading the effects of his own words and stance, Churchill has facilitated this degradation ceremony, and by association, of all of those who support him out of pre-set ideological commitments. How can it be otherwise when a recording (and the associated transcript) of Churchill (2003), giving public advice to a white male on committing acts of terrorism on U.S. national soil as recently as August 2003 at Seattle's Left Bank Bookstore, is easily available on the Internet? Here's a critical section:

Question from [white male in the] audience: 'Why did it take a bunch of Arabs to do what you all should have done a long time ago,' that's my question.

Churchill: I can't find a single reason that you shouldn't in a principled way-there may be some practical considerations, such as do you know how (laughter from audience)-you know, often these things are processes. It's not just an impulse. And certainly it's not just an event. And the simple answer is: You carry the weapon. That's how they don't see it coming. You're the one...They talk about 'color blind or blind to your color.' You said it yourself.

You don't send the Black Liberation Army into Wall Street to conduct an action... [or the] American Indian Movement into downtown Seattle. Who do you send? You. Your beard shaved, your hair cut close, and wearing a banker's suit.... There's where you start.

With any understanding the current media, information and perceptual environment, you don't intentionally send out Ward Churchill as a public speaker, unless you're allied with David Horowitz. Churchill is the perfect manifestation, and an excellent projection of Horowitz's private Manichean demons. Churchill is the primo poster boy for Horowitz's imagined legions of internal members of "the Fifth Column." Churchill is as useful to Horowitz as Alger Hiss was to a young California Congressman by the name of Richard Nixon. Like Whittaker and Hiss, the mere mention of Churchill's name may well be evoked, in future, to stigmatize citizens who are responsible dissenters. The ramped-up ability to hyper-generate and circulate discrediting accusations, to ply an army of "spoiled identities" upon members of any political opposition is a task that now utilizes the daily detritus of surveillant assemblages. Whether such outputs are accurate or not, whether these outputs impart the truth or frame lies and smears, is not of import, in a tactical sense. For imperfect protocols of pattern recognition means that assemblages serve up data to frame narratives for both imagined and real threats. It's a recipe for an incipient fascism.

Anyone who participates as a public intellectual in the early-twenty-first century must do so tactically, in a media-savvy manner, knowing that the multi-media surveillant assemblage is, well, continuously assembling, and then redistributing. It assembles and distributes, in sometimes surprising iterations, traces of utterances, images, sounds, motion and deeds. Inputs must be soberly assessed. We can assume that they will have unintended audiences. In the post-9/11 "society of insecurity," the outputs of the assemblage meld with the fears of "an endless war" that frame our Manichean moment. Within a generation, it may well be that a Horowitzian Manichaeism (with an enhanced, technologically-enabled dataveillance capability) ostensibly brought forth to protect us from the less sophisticated 
Manichaeism offered up by ideological and tactical dinosaurs of the 1970s, may well become the entrenched "Fifth Column," the enemy of freedom, that we will come, in short order, to fear and loath the most.

\section{| Counter-Tactics: Media Literacy in a Networked Age}

In a recent article in The Academic Exchange Quarterly (2004), I first discussed some of the problems inherent in current and general modes of K-16 learning and testing, in the United States:

Often, educational practices emphasize due deference and imitation ... Students are taught [to perform for] externally defined rewards ... and to appropriate masks of docility. . Standard notions of learning function as an academic version of bulimia. Students are expected to "binge," obediently taking in "foreign" ideas and then ritually purging in a frenzy of test-taking. While developing a type of tractability ... this approach frequently mistakes short-term memorization for the ability to create, apply and learn...

The article goes on to discuss the theoretical underpinnings, and practical assignments that are intended to create what Roland Barthes called "the writerly text." Such "texts" are the active construction of creative and alternative meanings that emerge from a fuller recognition of and engagement with mediated and textual products. In effect, students learn to recognize, and then deconstruct conventional assemblages of meaning. Post-analysis, they are encouraged to assemble new narratives, in the manner of the Levi-Straussian bricoleur.

Depending on the particular form of media, there are various ways to stimulate critical engagement. For example, if the object for analysis consists of local news reports, a detailed analysis that tracks visuals, via formal media protocols, can be useful. Such protocols emphasize the recognition and tracking of themes, images, tropes, and narrative segments. When properly taught, students begin move from the habits of distraction so common to media reception. In place of these distracted habits, students, taking the news as an object for analysis, begin to note the intertext that forms between the visual and auditory tracks. They also begin to apprehend the fact that the production of news involves the routinization of the nonroutine. They also begin to realize that the resulting construction (of a news item) is often an expression of the institutional priorities of ratings, news consultants, advertisers and political ideologists, rather than any kind of neutral window out into the world.

If the activity involves analyses of films, or cable television products, the ready availability of many scripts, plus the manipulative ease of the DVD format, can be easily melded with various semiotic approaches. Most films appropriate (or re-appropriate) a conventional stable of signifiers and signification patterns around a number of socio-cultural roles and scripts. Such stables of representational patterns usually include narratives around gender roles, race, class, and ethnicity, the market, the nature of social relations, as well as incorporating de facto ideologies of legitimacy and rationales for the exercise of various modes of power. The guts of this approach can also be applied to analyses of video games. The current generation of video games, exemplified by such popular products as Grand Theft Auto, Advanced Battlegrounds, and Mercenaries are, in many ways, distinctive artifacts of this particular cyber-Manichean moment. Semiotic analyses can explore the mimetic connections between cybernetic games, the Marinetti-like goal of remote, cybernetic warfare, and current Manichean-derived geopolitical discourse, policy and practice.

Other forms of analyses can take, as an object of study, the difference between the social construction of fact (as a form of truth telling), the propagation of opinion, and the creeping conflation of raw opinion with what Foucault called "games of truth." An additional and worthy task would be tracking current forms of pseudoargumentation and emotive appeals that mimic historically recognizable forms of propaganda. For pedagogical and political purposes, a key consideration would be to track how such techniques have been smartly refitted for twentyfirst century modes of representation and commodification.

While hardly exhaustive of approaches and techniques, this brief list embodies two urgent themes. First, we can identify the project as that of a reflexive cyber-epistemology. Cybernetic authentication networks and mediated worlds constitute much of how we know what we know. As technical ensembles and media formats change, our ways of apprehending and making sense of ourselves, and the world around us, concurrently change. On the most generalized level, all levels of schooling have done an inadequate job incorporating reflexive media literacy into curriculum. The result is a generation of students that may use technology, yes, but does not comprehend how such the formats of these market-based consumer technologies shape their worlds - their meaning, their identity, their 
ideology and their engagement or disengagement with conventional and emergent forms of politics.

The second urgent theme is an iteration of an ancient motif. In an age of simulation, interconnectivity, and the increasing implosion of the virtual into the real, what does it really mean, in such an age, to tell the truth? It's a question that is threaded through all the pedagogical techniques and approaches described above. It motivates the deeper, more necessary but less accessible processes of self-interrogation and honest confrontation. It is a question that will have to be insistently asked, and the subsequent answers must be incisively queried, and requeried, in the years to come.

\section{Coda}

I end this essay with a moral tale: It's instructive to remember the late Arthur Miller's mid-1950s refusal to "name names" in testimony to the House Un-American Activities Committee (HUAC). Far from a pathological gesture of pacifism (as Churchill would have it), Miller successfully fought the contempt of Congress citation. Subsequently, Miller (2003) was able to universalize his experience, through his play, The Crucible. Far from segregating the moral and political message to "politically correct" audiences, the play has broad cross-cultural, cross-national appeal, and is widely produced in a variety of languages. Miller still speaks to and for a global audience that recognizes such configurations, allegorically exposing encounters with Manichaeistic moments past and present, and the damage done. When we encounter these dueling projections of the Manichaeistic impulse, represented by Churchill and Horowitz, in the interstices of our daily lives, we would do well to remember Miller's cautionary tale, about the terrible cost of this form of boundary construction and maintenance, as we go about our professional and personal lives.

\section{Endnotes}

1. For purposes of discussion, Boyte's definition of the Manichean impulse will suffice:

American politics is now framed in Manichean terms associated with the mobilization of "innocents" against "evil doers" across the spectrum. Citizen groups on the left [and] right, demonize their opponents and proclaim their own virtues. . What is left out of citizenship . . . is the concept of the citizen as a creative, intelligent, and, above all, "political" agent. . . someone able to negotiate diverse views and interests for the sake of accomplishing some public task.

\section{References}

Boyte, Harry C. 2002. "A Different Kind of Politics: Dewey Lecture." Delivered at the University of Michigan, November 1st. Imagining America: Artists and Scholars in Public Life: A Web Resource for Campus-Community Partnerships. http:// www.ia.umich.edu/default.asp. Accessed on March 20, 2005.

Campos, Paul. 2005. "Real Question: How Did Prof Get on CU's Faculty in the First Place?" The Rocky Mountain News, February 5. Retrieved March 20, 2005 (http://www. rockymountainnews.com/drmn/news_columnists/ article/0,1299,DRMN_8_3524623,00.html).

Churchill, Ward. 2001. "Some People Push Back' On the Justice of Roosting Chickens." http://www.kersplebedeb.com/mystuff/s11/churchill.html. Alternate site: Staff. 2005. http://www.9news.com/acm_news. aspx ?OSGNAME $=$ KUSA\&IKOBJECTID $=$ cfee1069-0abe421a-00d6-36463de43888\&TEMPLATEID = 4525fe63-ac1f02d8-002a-f131478a1f55. Accessed March 20, 2005.

-.---. 2003. "Right On." From a talk delivered at the Left Bank Bookstore, Seattle, August 10, 2003. Audio excerpts and transcription. http://michellemalkin.com/archives/001588.htm. Accessed March 20, 2005.

...... 2005. "Embattled Professor Won't Back Down: Ward Churchill Weary of Fight." CNN.com, March 18, 2005. Retrieved March 20, 2005 Google Cache: (http://64.233.161.104/search?q=cache:-6KG_z1u4CoJ:www.cnn.com/2005/ EDUCATION/03/18/churchill. quotes.ap/+\%22 ward +churchill $\% 22++\% 22 \mathrm{I}+\mathrm{don} \% 27 \mathrm{t}$ +think+anybody+expected $\% 22 \& \mathrm{hl}=$ en). 
Dennis, Dion. 2001. "The World Trade Center and the Rise of the Security State." CTHEORY, Event Scene 098. Edited by Arthur and Marilouise Kroker. Retrieved March 20, 2005 www.ctheory.net/text_file?pick=299.

---- . 2002. "Priming the Pump of War: Toward a Post-Ethnic, Post-Racial Fascism." CTHEORY, Event Scene 115. Edited by Arthur and Marilouise Kroker. Retrieved March 20, 2005 www.ctheory.net/text_file?pick=353.

-.-- . 2004a. "Priming the Pump of War: Toward a Post-Ethnic, Post-Racial Fascism." Pp. 117-125 in Life in the Wires, edited by Arthur and Marilouise Kroker. Victoria: NWP, CTHEORY Books.

----. 2004b. "Media and Theory Through the Writing Process." Academic Exchange Quarterly, Spring 2004(8):1. Retrieved April 18, 2005 (http://www.rapidintellect.com/AEQweb/ cho24214w.htm).

Glazov, Jamie. 2005. "Symposium: Can Universities Be Fixed?" FrontPageMag.com, March 18. Retrieved March 20, 2005 (http://www.frontpagemag.com/Articles/ReadArticle. asp? ID=17406).

Haggerty, Kevin D., and Richard V. Ericson. 2000. "The Surveillant Assemblage." The British Journal of Sociology 51:605-22.
Hofstader, Richard. 1964. "The Paranoid Style in American Politics.” Originally published in Harper's Magazine, November, Pp. 77-86. Retrieved March 20, 2005 (http:// karws.gso.uri.edu/JFK/conspiracy_theory/ the_paranoid_ mentality/The_paranoid_style.html).

Horowitz, David. 2005. "What this Site is About." Retrieved March 20, 2005 (http://www.discoverthenetwork.org/groupProfile. asp? grpid $=7030)$.

-.--.. 2005a. "Individuals." Retrieved March 20. 2005 http:// www.discoverthenetwork.org/individual.asp

Media Matters. 2005. "David Horowitz’s "academic" standards: Under fire, right-wing campus watchdog admits Colorado exam story is phony after accusing Media Matters of slander," posted March 15th. http://mediamatters.org/items/200503160001 Accessed March 20, 2005.

Miller, Arthur. 2003. The Crucible. New York: Penguin Books.

Rogers, Richard. 2004. Information Politics on the Web. Cambridge: MIT Press.

Sherman, Scott. 2000. "David Horowitz's Long March, in The Nation, July 3rd. http://www.thenation.com/doc.mhtm1?=i20000703\&s=sherman Accessed March 20, 2005. 